\title{
WSTĘPNE ROZPOZNANIE GEOTECHNICZNE TERENÓW DOLIN RZECZNYCH POCHODZENIA ALUWIALNEGO POPRZEZ ZASTOSOWANIE ZDJĘĆ LOTNICZYCH I SATELITARNYCH
}

\begin{abstract}
Planowanie inwestycji budowlanych wymaga przeprowadzenia, często wnikliwych i wielokryterialnych analiz ich racjonalności. Jednym z czynników mających wpływ na ograniczenie kosztów przedsięwzięcia jest odpowiednie rozpoznanie geotechniczne. Dokładna analiza warunków gruntowych wymaga przeprowadzenia czasochłonnych i kosztownych badań. Często jednak już na wstępnym etapie planowania można wskazać zagrożenia mogące występować w podłożu. Pomocna może być w tym analiza zdjęć lotniczych i satelitarnych. W pracy przedstawione zostały możliwości wykorzystania takich zdjęć $i$ opartej na nich ortofotomapy do analizy geotechnicznej aluwialnych dolin rzecznych. Dzięki obecnie powszechnemu dostępowi elektronicznemu do wspomnianych materiałów ich wykorzystanie jest tym bardziej racjonalne. Tradycyjne mapy topograficzne nie są w stanie odwzorować wielu szczegółów morfologii terenu, przydatnych do wnioskowania o budowie podłoża gruntowego. W pracy opisano podstawowe procesy fluwialne kształtujące podłoże w dolinach rzecznych i jego krótką charakterystykę. Analizę morfologii terenu teras zalewowych, pod kątem opisu warunków geotechnicznych, przedstawiono na przykładzie wybranych fragmentów doliny rzeki Wisłoka.
\end{abstract}

Słowa kluczowe: ortofotomapa, zdjęcia lotnicze i satelitarne, doliny rzeczne, rozpoznanie geotechniczne

\section{Wprowadzenie}

Planowanie inwestycji powinno być oparte na optymalizacji uwzględniającej osiągnięcie maksymalnych korzyści przy zminimalizowaniu jej kosztów. Za korzyści należy uznać uzyskanie jak najlepszych właściwości użytkowych, również walorów estetycznych, a także zastosowanie materiałów o wysokiej jakości oraz zapewnienie odpowiedniej trwałości obiektu. Osiągnięcie wspo-

\footnotetext{
${ }^{1}$ Krzysztof Wilk, Politechnika Rzeszowska im. Ignacego Łukasiewicza, Wydział Budownictwa, Inżynierii Środowiska i Architektury, ul. Poznańska 2, 35-959 Rzeszów, tel. 178651006 , kwilk@prz.edu.pl.
} 
mnianych korzyści wiąże się z poniesieniem adekwatnych nakładów. Zastosowanie przez Inwestora tańszych rozwiązań przeważnie tożsame będzie z rezygnacją z pewnych, założonych do osiągnięcia parametrów. W praktyce jednak zdarzają się sytuacje, gdzie zmniejszenie kosztów nie będzie wiązać się z ograniczeniami jakościowymi i funkcjonalnymi. Ich redukcja wymaga dokładnej analizy pod kątem znalezienia rozwiązań zbędnych lub przesadzonych pod względem uzyskanych korzyści.

Jedną z przyczyn zwiększających wydatki inwestycyjne mogą być drogie rozwiązania fundamentowania budowli. Oczywiście muszą one zapewniać bezpieczeństwo obiektom, być adekwatne do wielkości obciążeń przekazywanych na podłoże, a przede wszystkim być dopasowane do warunków geotechnicznych w miejscu lokalizacji inwestycji.

Planowanie przedsięwzięcia budowlanego wynika $\mathrm{z}$ reguły $\mathrm{z}$ zapotrzebowania na konkretną infrastrukturę. W związku z tym, podczas jego umiejscawiania, warunki geotechniczne nie są przeważnie dominującym kryterium wyboru lokalizacji. Oczywiście, świadome planowanie inwestycji w trudnych warunkach gruntowych musi wynikać z jej nadzwyczajnego znaczenia. Niemniej jednak wstępny etap planowania uwzględnia czynniki społeczne, geograficzne, morfologiczne, komunikacyjne itp. Budowa podłoża gruntowego często analizowana jest dopiero po wykonaniu pierwszych opracowań geotechnicznych, a więc po (przynajmniej wstępnym) przyjęciu usytuowania obiektów. Niestety nie zawsze pomocne są $\mathrm{w}$ tym mapy geologiczne $\mathrm{z}$ uwagi na małą skalę, a tym samym niską dokładność.

Tymczasem niejednokrotnie analiza morfologii terenu opisanej za pomocą map topograficznych może dostarczyć wielu dodatkowych informacji odnośnie spodziewanych warunków gruntowych. Często jeszcze więcej wiedzy można uzyskać studiując zdjęcia lotnicze, satelitarne lub opartą na nich ortofotomapę. Dają one możliwość wnioskowania o zagrożeniach geotechnicznych z bardzo dużą dokładnością. $\mathrm{W}$ wielu przypadkach niewielkie przesunięcie $\mathrm{w}$ terenie obiektów planowanej inwestycji może dać znaczące oszczędności. Wykluczenie obszarów o potencjalnie niepewnej budowie podłoża, pozwala uniknąć zbędnych kosztów nawet samego rozpoznania geotechnicznego w nieodpowiednich miejscach. Ukształtowanie terenu zobrazowane na mapach topograficznych nie zawsze odzwierciedla możliwe trudności fundamentowania obiektów na danym terenie.

W niniejszej pracy przedstawione zostaną możliwości wykorzystania zdjęć lotniczych, satelitarnych i ortofotomapy w analizie przydatności terenów dolin rzecznych do celów budowlanych. Analizy dotyczyć będą perspektyw optymalizacji lokalizowania obiektów pod kątem ograniczenia kosztów fundamentowania. W analizach pominięto zagrożenie powodziowe, które jest oczywiste na terasach zalewowych i powinno być przedmiotem odrębnego rozpoznania. Ryzyko powodzi jest uzależnione od wysokościowego położenia terenu oraz technicznych zabezpieczeń przed zalewaniem podczas wezbrań rzeki. 


\section{Geotechniczne problemy występujące w dolinach rzecznych}

\subsection{Procesy ksztaltujące doliny rzeczne}

Jednymi z głównych zjawisk egzogenicznych kształtujących powierzchnię Ziemi są procesy fluwialne, związane $\mathrm{z}$ działalnością rzek [1, 12]. W bardzo dużym uproszczeniu polegają one na erodowaniu materiału skalnego (również rozdrobnionego i wcześniej zdeponowanego) z dna i brzegów, jego transporcie, a następnie osadzeniu wskutek utraty zdolności przemieszczania przez płynącą wodę.

Z biegiem rzeki zmienia się intensywność i charakter różnego rodzaju procesów fluwialnych. W górnych odcinkach cieków wodnych, z uwagi na znaczne spadki i duże prędkości przepływu, dominują procesy erozyjne, a wymiary cząstek dezintegrowanego i wleczonego materiału są znaczne. $\mathrm{Z}$ biegiem rzek przeważnie zmniejsza się gradient, a tym samym prędkość wody w ciekach. Ogranicza to ich zdolności transportowe, a tym samym powoduje wzrost znaczenia sedymentacji materiału skalnego. Na odcinku końcowym rzek ma miejsce niemal wyłącznie deponowanie materiału, a erozja obejmuje przeważnie tylko warstwy akumulacyjne. Dla natężenia poszczególnych procesów fluwialnych ma znaczenie nie tylko spadek dna i prędkość przepływu wody, ale również jej objętość [1]. Podczas wezbrań pobudzane są procesy erozyjne, natomiast w okresie suszy zwiększa się deponowanie materiału. Zdolność transportowa cieków wodnych zależy od prędkości oraz objętości przepływu, stąd granulacja osadzanego materiału maleje wraz z nurtem rzeki.

Zmniejszenie prędkości przepływu sprzyja meandrowaniu rzek i powstawaniu zakoli, które rozwijają się, a następnie, najczęściej podczas wezbrań ulegają odcięciu tworząc starorzecza $[11,12]$. Prędkość wody przy zewnętrznym brzegu meandra jest większa, zatem zwiększa się erozja boczna tej strony koryta. Tymczasem po stronie wewnętrznej, gdzie prędkość przepływu jest znacznie mniejsza odbywa się deponowanie materiału.

Rzeki w swych dolinach tworzą terasy zalewowe o charakterze erozyjnym lub akumulacyjnym (najczęściej jest to połączenie obu wymienionych form). Terasy natury erozyjnej powstają $\mathrm{w}$ wyniku erodowania zboczy podczas wezbrań. Erodowany materiał jest wymywany i transportowany w niższe partie cie$\mathrm{ku}$. Terasy akumulacyjne powstają $\mathrm{w}$ wyniku sedymentacji materiału na brzegach w czasie powodzi, czyli występowania rzek z koryt. Zaznaczyć należy, że bardzo często na terasach zalewowych widoczna jest zarówno działalność erozyjna, jak i akumulacyjna. Analizy terenów dolin rzecznych pod kątem morfogenezy ich powierzchni za pomocą zdjęć satelitarnych były już przedmiotem dociekań naukowych [4].

Zamieszczony powyżej opis zjawisk fluwialnych jest bardzo uproszczony i często wyidealizowany. Trzeba mieć świadomość, iż o ich rzeczywistym charakterze oraz intensywności na poszczególnych odcinkach cieków decyduje 
szereg naturalnych czynników miejscowych, losowych. Opis i określenie faktycznego wpływu przedmiotowych czynników często są bardzo trudne, o ile w ogóle możliwe. Decydują o tym procesy naturalne, nie spotkamy się zatem nigdy z dwoma rzekami, dolinami o takiej samej morfologii.

\subsection{Geotechniczna budowa podłoża w dolinach rzek}

Podłoże w obrębie teras wykształconych jedynie w wyniku procesów erozyjnych zbudowane może być z gruntów o zróżnicowanej genezie geologicznej. Będą to grunty powstałe jako rezultaty zjawisk zachodzących przed powstaniem cieków lub ich ekspansją. Niejednokrotnie może być to podłoże o znaczącym stopniu prekonsolidowania. Jako, że grunty na terasach natury erozyjnej powstały w wyniku innych procesów niż fluwialne, nie będą poddane dalszej analizie.

Na terasach o charakterze akumulacyjnym podłoże gruntowe jest zbudowane $\mathrm{z}$ materiału deponowanego, przetransportowanego z góry rzeki. Będzie to zatem niejednorodny grunt o składzie mineralogicznym adekwatnym do gruntów budujących doliny cieku powyżej analizowanego przekroju. Z uwagi na zmienną siłę wezbrań często osadzany materiał będzie posiadał warstwową budowę, z wyraźnym pionowym rozsegregowaniem wymiarowym ziaren i cząstek gruntu.

W materiale akumulacyjnym należy uwzględnić pewną zawartość części organicznych pochodzących z dwojakiego źródła: przywleczonych przez nurt rzeki, bądź wegetujących $\mathrm{w}$ danej lokalizacji i obumarłych wskutek pokrycia sedymentem [14].

Zwiększonej zawartości części organicznych należy spodziewać się w miejscu zastoisk powstałych w odciętych meandrach rzek. Jest to efektem stopniowego zarastania tych zbiorników wodnych. Podobnie lokalizację gruntów o podwyższonej zawartości części organicznych można przewidywać po wewnętrznej stronie zakoli rzecznych, również starorzeczy.

Podsumowując obszary dolin rzecznych posiadają bardzo złożoną budowę geotechniczną. Wyraża się to zarówno zmiennością lokalną gruntów spowodowaną różnymi warunkami deponowania materiału, jak i zmiennością w obrębie pojedynczych profili [14]. Przyczyną tego stanu rzeczy jest między innymi zróżnicowana siła wezbrań. Co więcej niskie wartości parametrów geotechnicznych to nie jedyny problem takich terenów. Często zauważalna jest również ich miejscowa niestabilność związana ze zmianami zawilgocenia. Wahania wilgotności gruntu powiązane są $\mathrm{w}$ tym przypadku $\mathrm{z}$ wezbraniami cieków podczas intensywnych opadów oraz obniżaniem poziomu wody w okresach suchych $[8$, 9]. Filtracja wód gruntowych jaka ma miejsce w podłożu powstałym w wyniku akumulacyjnej działalności rzek jest bardzo złożona i nie zawsze będzie rzetelnie odzwierciedlana przez tradycyjny parametr, jakim jest współczynnik filtracji [15]. 


\section{Zastosowanie ortofotomapy we wstępnej analizie geotech- nicznej podłoża $w$ dolinach rzecznych}

\subsection{Zdjęcia lotnicze i satelitarne}

Przed laty dostępność do materiałów fotograficznych wykonywanych z dużych wysokości z samolotów lub satelity była mocno utrudniona, zarówno ze względu na ówczesne możliwości techniczne, jak i z uwagi na pojmowane wówczas bezpieczeństwo kraju. Obecnie taki dostęp można powiedzieć, że jest powszechny, dzięki między innymi takim portalom jak: www.google/maps/, www.satelitarnamapapolski.pl, www.geoportal.gov.pl. Co więcej zakres udostępnianych informacji ciągle się zwiększa, tak samo rośnie dokładność odwzorowań powierzchni Ziemi.

Zdjęcia lotnicze i satelitarne są doskonałym narzędziem analizy powierzchni terenu. Po ich odpowiedniej rektyfikacji i przetworzeniu nawiązującym do stosownego układu odniesienia (układu współrzędnych) tworzą one ortofotomapę, na podstawie której możemy dosyć precyzyjnie określić położenie różnych obiektów [3]. Tym samym możliwe jest ustalenie lokalizacji pewnych form geomorfologicznych, które mogą być interesujące podczas analizy ortofotomapy pod kątem minionych i obecnych zjawisk geologicznych kształtujących podłoże gruntowe [2].

Ten aspekt zastosowania zdjęć terenu wykonywanych z samolotu, bądź $\mathrm{z}$ satelity zostanie przedstawiony dalej w odniesieniu do dolin rzecznych o charakterze akumulacyjnym. Przykładowe rozważania dotyczyć będą wybranych fragmentów doliny rzeki Wisłoka. Oparte zostały na ortofotomapie i mapach topograficznych udostępnionych w serwisie internetowym Głównego Urzędu Geodezji i Kartografii www.geoportal.gov.pl oraz portalach powiatowych.

Podczas dedukcji na temat budowy podłoża, bardzo pomocna może okazać się analiza szaty roślinnej na danym obszarze [10]. Niestety w przypadku nizinnych dolin rzecznych jest ona przeważnie bardzo uboga. Są to tereny, gdzie gleby są żyzne, a przez to w maksymalnym stopniu wykorzystywane rolniczo. Łąki, tak jak to ma miejsce również na obszarach o innej budowie geologicznej i innej morfologii, przeważnie świadczą o znacznym zawilgoceniu i najczęściej obniżeniu terenu.

\subsection{Przykłady analiz doliny rzeki Wisłoka}

Rzeka Wisłoka jest prawobrzeżnym dopływem górnej Wisły. Wypływając z Beskidu Niskiego w Karpatach kieruje się na północ (kierunek południkowy) i przepływając Kotliną Sandomierską przez Zapadlisko Przedkarpackie [13] wpada do największej polskiej rzeki. Bieg dolny Wisłoki (doliną o charakterze akumulacyjnym) rozpoczyna się w okolicach miasta Jasło. 
W dalszej części pracy zaprezentowane zostały zdjęcia ortofotomapy przedstawiające różnorodność form pozostawionych przez dawne koryta rzeki (rys. 1a., rys. 2a., rys. 3a.). Ich rozlokowanie powierzchniowe powinno nasuwać szereg wniosków odnośnie jakości podłoża gruntowego i zagrożeń geotechnicznych na analizowanym terenie. Celem porównania zamieszczone zostały również zdjęcia map topograficznych takich samych obszarów (rys. 1b., rys. 2b., rys. 3b.). Dokładność i zakres zawartych na mapach informacji nie jest w stanie dorównać możliwościom, jakie daje interpretacja materiałów opartych na zdjęciach lotniczych i satelitarnych.

Na ortofotomapie widać, że większość starorzeczy akcentuje sposób użytkowania terenu, w tym kształt działek. Nie jest to jednak regułą. Analizując zdjęcia należy zwrócić uwagę także na różnice kolorystyczne na powierzchniach terenu użytkowanych w taki sam sposób. Sugerują one dodatkowe, nie wydzielone obszary osłabienia podłoża, które posługując się innymi rodzajami map byłoby trudno zlokalizować.

W odniesieniu do starorzeczy, na zamieszczonych poniżej przykładowych zdjęciach (rys. 1., rys. 2., rys. 3.) zauważyć można m.in.:

- wyraźne znaczne obniżenia terenu widoczne zarówno na ortofotomapie, jak i na mapie topograficznej, często są to zbiorniki wodne lub zakola porośnięte roślinnością bagienną, drzewami, zalegające w nich części organiczne będą miały niski stopień rozkładu, $\mathrm{z}$ tego powodu nie zostały one zagospodarowane przez człowieka - na rysunkach opisane symbolem A,

- znaczne obniżenia terenu (ortofotomapa i mapa topograficzna), których ukształtowanie powoduje podział areału $\mathrm{z}$ uwagi na sposób wykorzystania - symbol B,

- duże obniżenia terenu wykazane na ortofotomapie i na mapie topograficznej, które nie decydowały o zmianie użytkowania powierzchni terenu - oznaczone symbolem C,

- starorzecza widoczne na ortofotomapie, lecz niezauważalne lub trudne do dostrzeżenia na mapie topograficznej, o małym zróżnicowaniu wysokościowym, przez co mogą zostać rozpoznane wyłącznie ze względu na różnice $\mathrm{w}$ intensywności wzrostu roślinności i zawilgocenia - na rysunkach opisane symbolem D,

- lokalizacje przypuszczalnych, lecz niewidocznych na zdjęciach lotniczych tras meandrów rzecznych, najczęściej na przedłużeniach ramion obserwowanych starorzeczy - symbol E. 


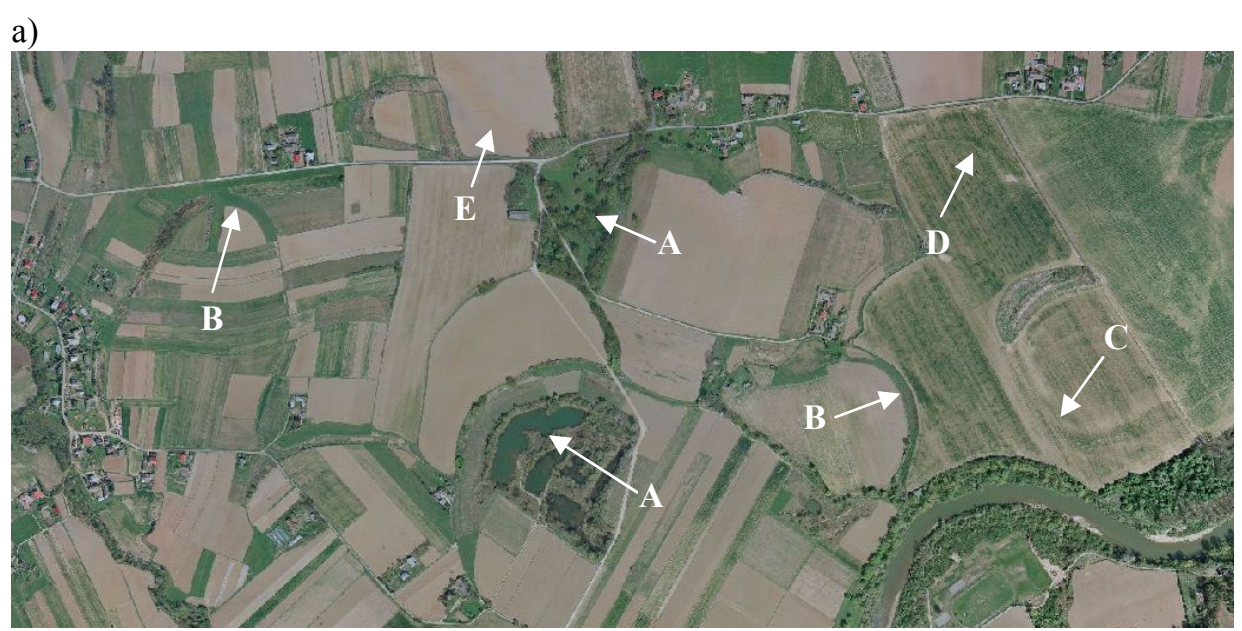

b)

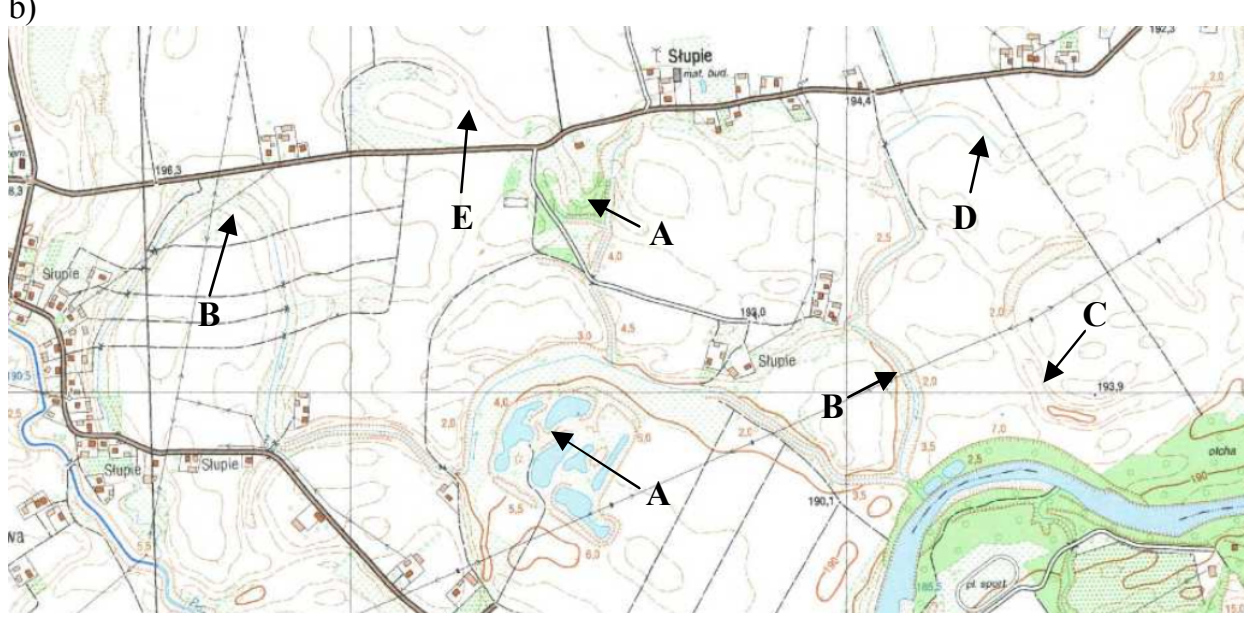

Rys. 1. Dolina rzeki Wisłoka w rejonie miejscowości Chotowa: a) ortofotomapa (skala 1:20 000) [5]; b) mapa topograficzna (skala 1:20 000) [6].

Fig. 1. Valley of Wisloka river near Chotowa: a) orthophotomap (scale 1:20 000) [5]; b) topographic map (scale 1:20 000) [6].

Rozpoznanie różnych, opisanych wcześniej typów obszarów w obrębie dolin rzecznych, zróżnicowanych morfologiczne i geologiczne jest o wiele łatwiejsze na zdjęciach satelitarnych niż przy pomocy map topograficznych. 
a)

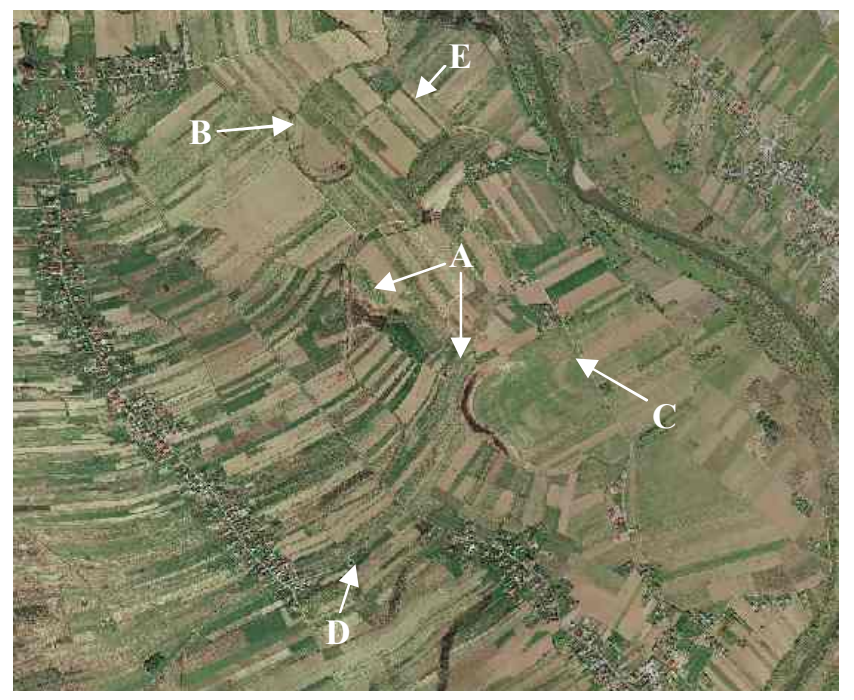

b)

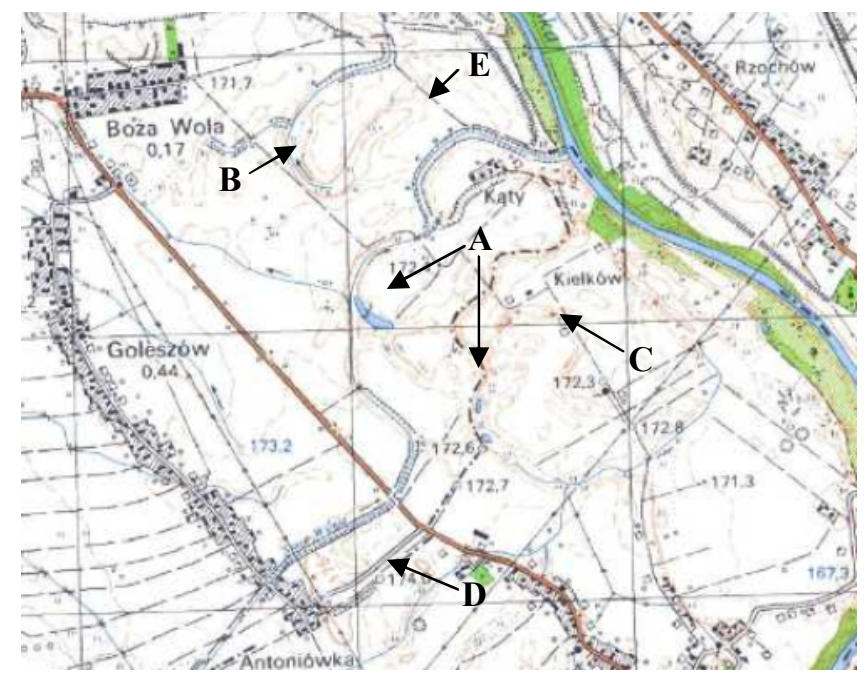

Rys. 2. Dolina rzeki Wisłoka w rejonie miejscowości Goleszów i Kiełków: a) ortofotomapa (skala 1:40 000) [7]; b) mapa topograficzna (skala 1:40 000) [6].

Fig. 2. Valley of Wisloka river near Goleszow and Kielkow: a) orthophotomap (scale 1:40 000) [7]; b) topographic map (scale 1:40 000) [6]. 


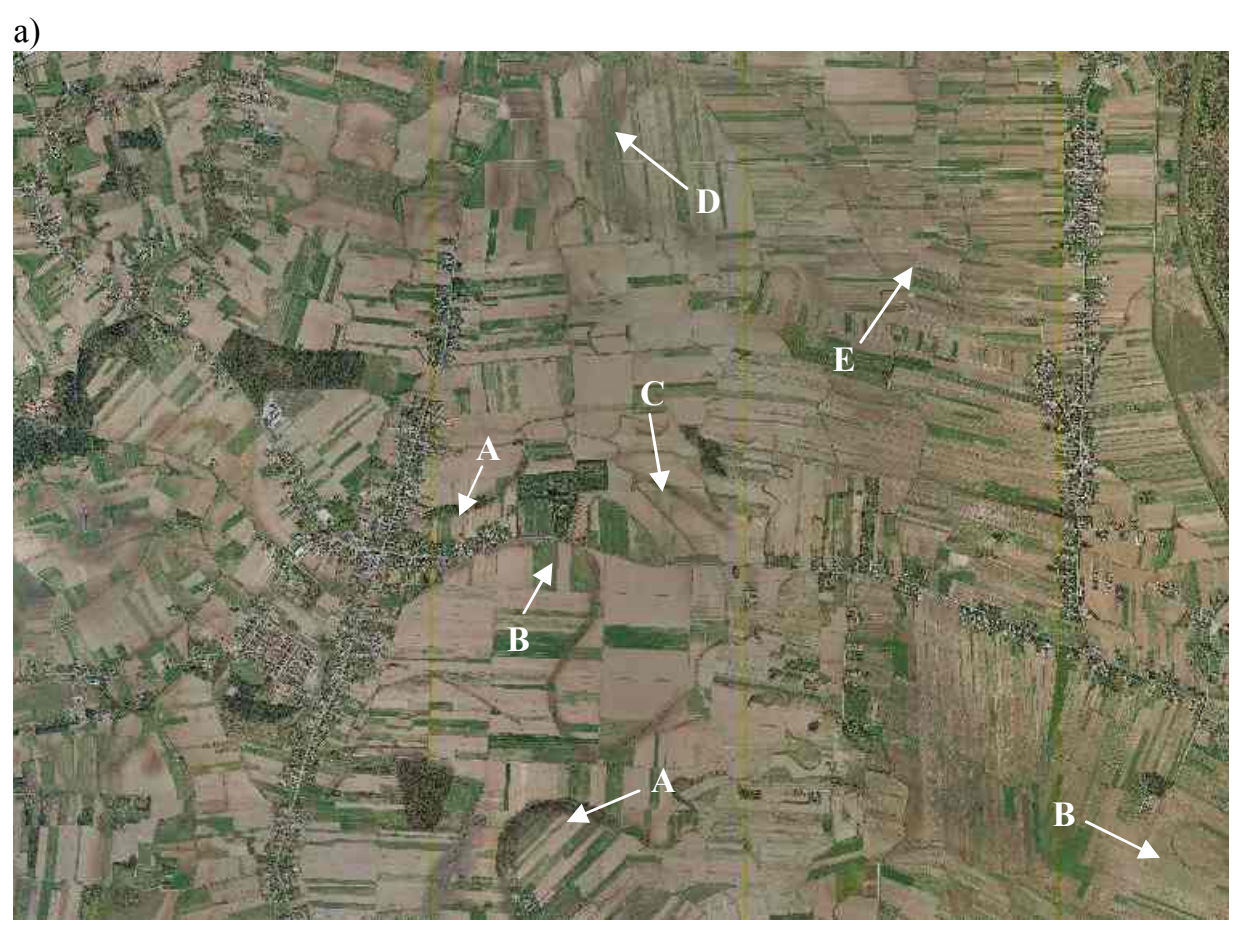

b)

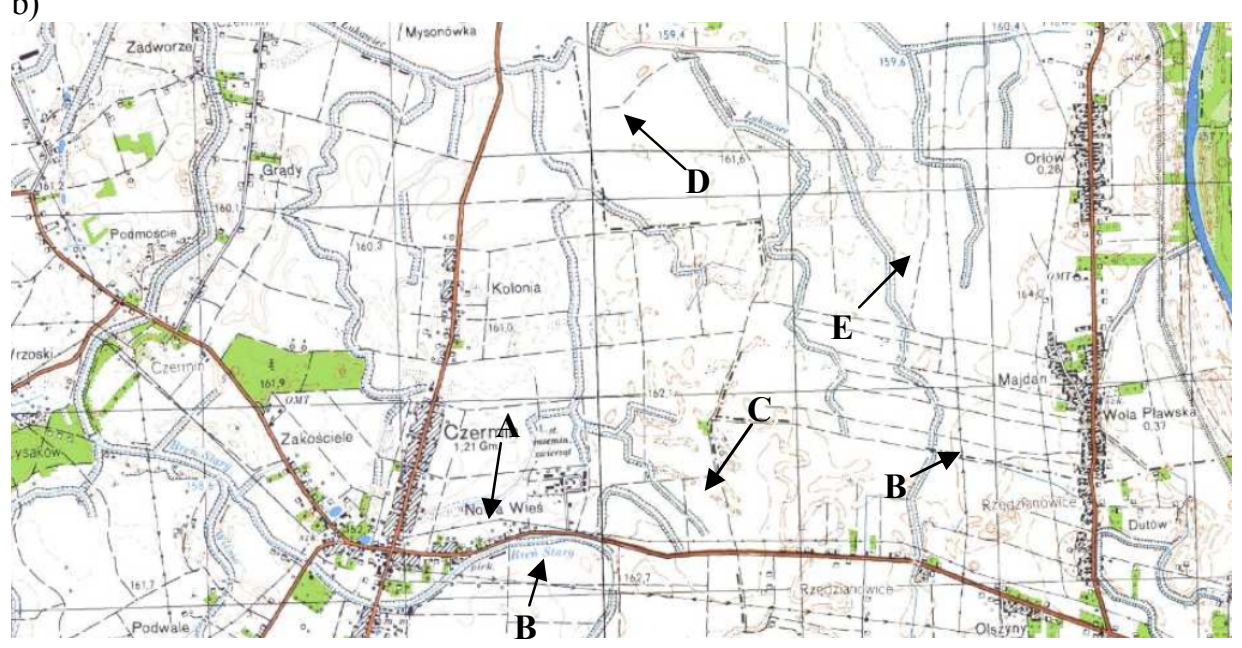

Rys. 3. Dolina rzeki Wisłoka w rejonie miejscowości Czermin i Wola Pławska: a) ortofotomapa (skala 1:50 000) [7]; b) mapa topograficzna (skala 1:50 000) [6].

Fig. 3. Valley of Wisloka river near Czermin i Wola Plawska: a) orthophotomap (scale 1:50 000) [7]; b) topographic map (scale 1:50 000) [6]. 
$\mathrm{Na}$ rysunku 3. obszar oraz gęstość różnorodnych form pochodzenia fluwialnego jest wydatnie większa niż obserwowana na rysunku 1. i rysunku 2. Jest to spowodowane niewielką odległością (około $7 \mathrm{~km}$ ) od znacznie większej rzeki Wisły, w której ma swoje ujście Wisłoka. Tym samym częstość i intensywność stanów powodziowych na przedmiotowej terasie zalewowej jest istotnie większa niż pozostałych przypadkach.

\section{Podsumowanie}

Należy stwierdzić, że analiza zdjęć lotniczych może być doskonałym narzędziem do wstępnego ustalenia lokalizacji przyszłych obiektów budowlanych na terenach teras zalewowych. Jest to sposób pozwalający na oszczędność czasu i środków związanych z przeprowadzeniem badań geotechnicznych, a także niejednokrotnie $\mathrm{w}$ dalszej kolejności również funduszy finansujących realizację inwestycji, szczególnie w odniesieniu do rozwiązań fundamentowych.

Oczywiście analiza ortofotomapy nie da odpowiedzi na temat ilościowych wartości parametrów gruntu (nawet szacunkowych), ale może pozwolić uniknąć terenów, gdzie zdeponowane zostały grunty słabonośne, przede wszystkim zawierające znaczącą ilość części organicznych. Sposób powstawania podłoża na obszarach dolin rzecznych to osadzanie materiału przemieszczanego przez wartki nurt rzeki, jego powolna sedymentacja w strefach o niższej prędkości wody, ewentualnie zarastanie, a następnie rozkład części organicznych w zbiornikach odciętych meandrów. Wiedza o charakterze rozwoju cieków wodnych $\mathrm{i}$ ich dolin pozwala na przybliżone określenie rodzaju gruntów zalegających w danej lokalizacji, ich możliwej granulacji oraz zagęszczeniu (porowatości).

Interpretacja fotografii wykonanych z powietrza daje przede wszystkim pewien pogląd na temat niejednorodności w budowie podłoża, która często będzie bardziej niebezpieczna dla posadowienia obiektów budowlanych, niż niskie wartości parametrów wytrzymałościowych i odkształceniowych. Tym samym można zauważyć konieczność zmiany sposobu fundamentowania poszczególnych części budynków (zwłaszcza wielkopowierzchniowych), a nawet określić miejsca zastosowania dylatacji.

Przegląd zdjęć lotniczych na etapie planowania inwestycji, może pozwolić również na przybliżone oszacowanie kosztu rozwiązań posadowienia. Gdy wartość robót fundamentowych będzie znacząca, może to mieć wpływ na nakłady dla całego planowanego zamierzenia.

Możliwość obserwacji i jednoczesnej analizy dużej powierzchni terenu daje szansę dostrzeżenia wielu dodatkowych, a niekiedy nawet dominujących, czynników warunkujących jakość podłoża. Okoliczności te podczas lustracji małego obszaru (np. ortofotomapy o dużej skali) lub przeprowadzania wizji terenowej pozostają ukryte. 
Wstępny wybór umiejscowienia obiektów na podstawie zdjęć lotniczych musi zostać potwierdzony wizją lokalną, a dalej badaniami geotechnicznymi: wstępnymi i zasadniczymi.

\section{Literatura}

[1] Bajkiewicz-Grabowska E., Mikulski Z.: Hydrologia ogólna, Wydawnictwa Naukowe PWN, Warszawa 2013.

[2] Ciołkosz A., Miszalski J., Olędzki J.R.: Interpretacja zdjęć lotniczych, Państwowe Wydawnictwo Naukowe, Warszawa 1978.

[3] Dorozhynskyy O., Tukaj R.: Fotogrametria, Wydawnictwo Politechniki Lwowskiej, Lwów - Kraków 2009.

[4] Falkowski T., Ostrowski P.: Morfogeneza powierzchni tarasu zalewowego Wisły w okolicach Magnuszewa w obrazie zdjęć satelitarnych i lotniczych, Infrastruktura i Ekologia Terenów Wiejskich, Nr 9/2010, Polska Akademia Nauk Oddział w Krakowie, 2010, s. 89-100.

[5] http://debica.geoportal2.pl/map/www/mapa.php?CFGF=wms\&mylayers=+granice +OSM+ (dostęp: 04 listopada 2015)

[6] http://mapy.geoportal.gov.pl/imap/?gpmap=gp0\&actions=acShowWgButtonPanel kraj_ORTO (dostęp: 04 listopada 2015)

[7] http://mielec.geoportal2.pl/map/www/mapa.php?CFGF=wms\&mylayers=+granice +OSM+ (dostęp: 04 listopada 2015)

[8] Jaremski J., Wilk K.: Analiza wpływu zmian zawilgocenia gruntów madowych wywołanych stanami powodziowymi na parametry geotechniczne, Zeszyty Naukowe Politechniki Rzeszowskiej, nr 208, Budownictwo i Inżynieria Środowiska, z. 36, Oficyna Wydawnicza Politechniki Rzeszowskiej, 2004, s. 47-53.

[9] Jaremski J., Wilk K.: Wpływ zmian parametrów geotechnicznych wywołanych stanami powodziowymi na obiekty budowlane, XII Ogólnopolska Szkoła Gospodarki Wodnej „Ochrona przeciwpowodziowa w społeczeństwie informacyjnym”, Instytut Meteorologii i Gospodarki Wodnej, Warszawa 2002, s. 17-21.

[10] Jeż J.: Biogeotechnika, Wydawnictwo Politechniki Poznańskiej, Poznań 2008.

[11] Migoń P.: Geomorfologia, Wydawnictwa Naukowe PWN, Warszawa 2013.

[12] Mizerski W.: Geologia dynamiczna, Wydawnictwa Naukowe PWN, Warszawa 2015.

[13] Mizerski W.: Geologia Polski, Wydawnictwa Naukowe PWN, Warszawa 2014.

[14] Myślińska W.: Grunty organiczne i laboratoryjne metody ich badania, Wydawnictwa Naukowe PWN, Warszawa 2001.

[15] Wilk K.: Badanie wodoprzepuszczalności gruntów spoistych akumulacji rzecznej, Inżynieria Morska i Geotechnika, Nr 1/2007, IMOGEOR Sp. z o.o., 2007, s.32-36. 


\title{
PRELIMINARY GEOTECHNICAL RECOGNITION OF THE RIVER VALLEY AREAS OF ALLUVIAL ORIGIN BY APPLICATION THE AERIAL AND SATELLITE PHOTOS
}

\begin{abstract}
S u m m a r y
The planning of civil investments often requires insightful and multi-criteria analyzes of their rationality. Appropriate geotechnical recognition is one of the factors influencing the cost of the project. A thorough analysis of ground conditions requires a time-consuming and expensive procedure. However, often we identify hazards that can occur in the substrate at early stage of planning. The analysis of aerial and satellite photos may be helpful in this problem. The paper presents the possibilities of using such photos and orthophotomap based on them for preliminary geotechnical analysis of alluvial river valleys. Their use is more commonly through the currently public electronic access to these materials. Traditional topographic maps are not able to reproduce many of the details of the terrain morphology that are useful to interferences for the ground conditions. This paper described the basic fluvial actions shaping the substrate in river valleys and its brief characteristics. Analysis of the morphology of the terrain floodplain terrace, for description of geotechnical conditions, has been exhibited on examples of selected parts of the Wisloka river valley.
\end{abstract}

Keywords: orthophotomap, aerial and satellite photos, river valleys, geotechnical recognition

Przesłano do redakcji:30.05.2015

Przyjęto do druku:10.01.2016

DOI: $10.7862 / \mathrm{rb} .2015 .212$ 